\title{
Utilization of microbial selenium collected from the rumen of sheep
}

\author{
T. Ohgushi-Imamura ${ }^{1}$, E.A. Orden ${ }^{2}$ and T. Fujihara ${ }^{3,4}$ \\ 1Shimane University, Faculty of Life and Environmental Science, Matsue City, 690-8504, Japan \\ ${ }^{2}$ SRC, Central Luzon State University, Science City of Munoz Nueva Ecija, Philippines 3120 \\ ${ }^{3}$ Philippine Carabao Center, Science City of Munoz, Nueva Ecija, Philippines 3120
}

KEY WORDS: rat, rumen microbial Se, selenite, Se utilization

Received: 15 November 2013

Revised: 4 March 2014

Accepted: 12 June 2014

${ }^{4}$ Corresponding author:

e-mail: tfuji1943@yahoo.co.jp
ABSTRACT. The bioavailability of incorporated Se from bacteria and protozoa collected from rumen of sheep was investigated using female Wistar rats to simulate the lower digestive tract of a ruminant. The rats were fed diets supplemented with different sources of Se, namely: control - without Se, ISe - with selenite, PSe - with protozoan Se, BSe - with bacterial Se. After a 7-day feeding trial, blood samples were collected through the abdominal aorta and all animals were slaughtered for organ and tissue samples. The Se absorption and retention in PSe or BSe was almost similar to that in ISe, although the variation was quite high in microbial Se. The whole-blood Se level in BSe and PSe was similar, though numerically higher in PSe than BSe. Se levels in the liver and kidney also tended to be higher in ISe than in PSe or BSe. The results suggest that microbial Se can be efficiently utilized, although bacterial Se is more available and comparable to selenite in terms of retained Se relative to what is absorbed. Se from protozoa appeared to be less available than selenite, as judged by the smaller amount of Se in some organs of rats fed PSe than in those in the ISe group.

\section{Introduction}

Selenium (Se) is a non-metallic element with a chemical nature similar to sulphur and is an essential mineral for animals. Its concentration in the earth's crust is $0.1 \mathrm{ppm}$, with wide variation depending on the area (Saruwatari and Ikeda, 1993). Selenium was formerly considered a poisonous substance for animals, but recently its physiological and nutritional importance has been pointed out and it is now recognized as an essential element.
In animal nutrition, the requirement range of $\mathrm{Se}$ is very narrow, e.g., $50-300 \mathrm{ng} \cdot \mathrm{g}^{-1} \mathrm{DM}$ in feeds for ruminants. Since ruminant feeds have an Se content range from 100 to $5000 \mathrm{mg} \cdot \mathrm{kg}^{-1} \mathrm{DM}$, the occurrence of both toxicity and deficiency is very likely (NRC, 1983; McDowell, 1985).

In most tropical and subtropical areas of the world, the Se content of the soil is generally low due to heavy rainfall and soil erosion, thereby exposing grazing animals to Se deficiency (Harrtey, 1963; Trinder et al., 1969; Fujihara et al., 1992). 
It is, therefore, imperative that some form of feeding intervention be practiced to prevent clinical or subclinical Se deficiency symptoms.

Inorganic (selenite and selenate) and organic (selenocysteine and selenomethionine) selenium are known to be nutritionally useful. Se exists as selenocystine, selenocysteine, selenomethionine, or Semethyl selenomethionine in most cereals or forages (NRC, 1983; Serra et al., 1996). In practice, selenate and selenite are used as supplements in Se-deficient diets (Nicholson et al., 1991; Saruwatari and Ikeda, 1993). Conversely, Se in the animal body is mostly in an organic form that is bound with amino acids. Increased biosynthesis of Se-proteins provides protection against oxidative stress in muscles and other vital organs of mammals (Schomburg et al., 2004).

There are several factors that influence Se bioavailability in ruminants, including antagonism to sulphur $(\mathrm{S})$ and reciprocity with copper $(\mathrm{Cu})$, where a positive response to Se supplementation was observed in Cu-deficient sheep (NRC, 1985). Some reports pointed out the interrelationships of Se with mercury, arsenic (As) and cadmium (Cd) (Hidiroglou et al., 1968; Whanger et al., 1978; McDowell, 1985; Grosicki and Kowalski, 2002). Moreover, Se availability could be influenced by animal species and the protein and conjugated linoleic acid contents of the diet (Schomburg et al., 2004; Czauderna et al., 2011).

Serra et al. (1994) demonstrated that the bioavailability of selenite and selenate is similar in providing supplemental Se to sheep. Conversely, Se absorption among ruminants is low after its incorporation into microbial tissue under a highly reduced rumen environment (Cousins and Cairney, 1961; Peterson and Spedding, 1963; Hidiroglou et al., 1968; Paulson et al., 1968; Harrison and Conrad, 1984; Hudman and Glenn, 1984; Lyons et al., 2006). In vitro experiments revealed that about $40 \%$ of rumen microbial selenite is converted to an insoluble form, while the incorporation of Se into microbial cell walls is more efficient and faster. Selenium was incorporated into bacterial protein within an hour post feeding, reaching a peak level in 2 hours (Hidiroglou et al., 1968). Recent findings showed that the addition of conjugated linoleic fatty acids (CLA) to diets enriched with selenized yeast $\left(0.5 \mu \mathrm{g} \mathrm{Se} \cdot \mathrm{g}^{-1}\right)$ stimulated the accumulation of Se in the liver and muscle of rats (Czauderna et al., 2011). These authors attributed the increased Se biosynthesis to elevated oxygen consumption associated with higher oxidation of fat. Furthermore, they pointed out that dietary inorganic Se (selenate) or organic Se (as selenized Se) exhibited a similar influence on the metabolic capacity of CLA isomers in rats (Czauderna et al., 2004, 2011).

In view of the recent developments on $\mathrm{Se}$ nutrition and limited information on the utilization of bacterial Se and protozoal Se (Durand and Kawashima, 1980; McDowell, 1985), the current study was conducted to determine the utilization of rumen microbial Se using rats as the experimental animal to simulate the lower digestive tract of ruminants. Likewise, Czauderna et al. (2011) indicated that $\mathrm{Se}$ in tissues of mammals reflects the chemical form of Se and its level in the consumed diet. Therefore, the Se concentration in the muscles and other organs such as the liver, kidney, lungs, brain and heart were analysed to estimate the Se bioavailability of microbial Se. Part of the results of this work were published by Fujihara et al. (2004).

\section{Material and methods}

\section{Preparation of microbial Se}

Two rumen-fistulated sheep (castrated male and female: average body weight $39.3 \pm 1.7 \mathrm{~kg}$ ) were used as sources of microbial tissue Se. They were fed a mixed diet consisting of timothy hay and concentrate (wheat bran and soyabean meal, 3:1/dry matter (DM), 3:2/DM) to meet the daily energy requirement of $0.4 \mathrm{MJ}$ per $\mathrm{kgW}^{0.75}$. Selenite (Wako Pure-chemical Industrial Co.) was incorporated at the rate of $0.4 \mathrm{mg} \cdot \mathrm{kg}^{-1} \mathrm{DM}$ (Fujihara and Ichinohe, 2012).

A sufficient amount of rumen liquor was collected from the host animals $2 \mathrm{~h}$ post Se-feeding and filtered to separate solids from the liquid. The filtrate was mixed with $0.1 \mathrm{M}$ sucrose at a 3:1 ratio (v/v) in a separation flask and incubated at $39^{\circ} \mathrm{C}$ for $2 \mathrm{~h}$, which allowed segregation of feed particles, bacteria and protozoa. Protozoa were separated by low-speed centrifugation, washed, and dried for $48 \mathrm{~h}$ at $60^{\circ} \mathrm{C}$, while the bacterial layer was further centrifuged at $20000 \mathrm{~g}$ for one $\mathrm{h}$ and the sediment dried. Dried bacteria and protozoa matter was ground and stored at $4^{\circ} \mathrm{C}$ prior to incorporation in the experimental diets.

\section{Experimental animals and diets}

A total of 43-female Wistar rats (8 weeks old) were used in the study. They were kept in individual cages in a temperature controlled room at $23^{\circ} \mathrm{C}$ and randomly assigned to the one of the 4 dietary treatments as follows: control - without Se supplement (12 animals); $\mathrm{kg}^{-1} \mathrm{DM}$ : ISe - inorganic Se (0.1 mg selenite $\mathrm{Se})$ (11 animals); PSe - $0.1 \mathrm{mg}$ protozoal Se (10 animals); BSe - $0.1 \mathrm{mg}$ bacterial Se (10 animals). 
Table 1. Percent diet composition and nutrient contents of the different treatments

\begin{tabular}{|c|c|c|c|c|}
\hline \multirow{2}{*}{$\begin{array}{l}\text { Indices } \\
\text { Ingredients, \% }\end{array}$} & \multicolumn{2}{|c|}{ Control ${ }^{1} \mathrm{ISe}^{2}$ diet } & \multicolumn{2}{|c|}{$\mathrm{PSe}^{3}$ diet BSe $\operatorname{diet}^{4}$} \\
\hline & & & & \\
\hline rumen microbial matter & - & - & 22.2 & 32.2 \\
\hline selenite & - & 0.002 & - & - \\
\hline casein $^{5}$ & 20.0 & 20.0 & 12.6 & 9.2 \\
\hline DL-methionine & 0.3 & 0.3 & 0.3 & 0.3 \\
\hline maize starch & 15.0 & 15.0 & 15.0 & 15.0 \\
\hline sucrose & 50.0 & 50.0 & 35.2 & 28.6 \\
\hline cellulose & 5.0 & 5.0 & 5.0 & 5.0 \\
\hline maize oil & 5.0 & 5.0 & 5.0 & 5.0 \\
\hline vitamin mixture ${ }^{6}$ & 1.0 & 1.0 & 1.0 & 1.0 \\
\hline cholin-acid tartrate & 0.2 & 0.2 & 0.2 & 0.2 \\
\hline mineral mixture (Se free $)^{7}$ & 3.5 & 3.5 & 3.5 & 3.5 \\
\hline \multicolumn{5}{|l|}{ Nutrient, \% DM } \\
\hline dry matter & 95.3 & 95.3 & 93.5 & 90.7 \\
\hline organic matter & 97.1 & 93.8 & 92.3 & 89.1 \\
\hline crude protein & 15.0 & 15.0 & 15.0 & 15.0 \\
\hline crude fat & 3.3 & 5.0 & 5.7 & 3.9 \\
\hline
\end{tabular}

${ }^{1}$ calculated based on AIN-76 (NRC, 1978). (0.051 mg Se $\cdot \mathrm{kg}^{-1}$ dietary DM); ${ }^{2}$ added with selenite (Wako purechemical Co.) (0.1 mg Se $\left.\cdot \mathrm{kg}^{-1} \mathrm{diet}\right) ;^{3}$ added protozoa fraction $\left(0.1 \mathrm{mg} \mathrm{Se} \cdot \mathrm{kg}^{-1}\right.$ diet); ${ }^{4}$ added bacterial fraction $\left(0.1 \mathrm{mg} \mathrm{Se} \cdot \mathrm{kg}^{-1}\right.$ diet); ${ }^{5} 85 \%$ crude protein; ${ }^{6}$ Panbitan powder (per g) (Takeda Medicine Industrial Co.): IU: vit. A 2500 , vit. $D_{3} 200$; mg: vit. E 1.0, vit. K 0.5, ascorbic acid 37.5, riboflavin 1.5, thiamine-mono-nitrate 1.0, pyridoxine hydrochloride 1.0, Ca-pantothenate 5.0, nicotinic acid 10.0; $\mu \mathrm{g}$ : cyanocobalamine 1.0; ${ }^{7} \mathrm{AlA}-76$ combine mineral (\%) (Oriental Yeast Industrial $\mathrm{Co}$.): $\mathrm{C}_{2} \mathrm{HPO}_{4}, 50.0, \mathrm{NaCl} 7.4, \mathrm{~K}_{3} \mathrm{C}_{6} \mathrm{H}_{5} \mathrm{O}_{7} . \mathrm{H}_{2} \mathrm{O}$ 22.0, $\mathrm{K}_{2} \mathrm{SO}_{4}$ 5.2, $\mathrm{MgO} 2.4, \mathrm{MnCO}_{3}$ 0.35, Fe-citrate (Fe 17\%) 0.6 , $\mathrm{ZnCO}_{3} 0.16, \mathrm{CuCO}_{3} . \mathrm{Cu}(\mathrm{OH})_{2} . \mathrm{H}_{2} \mathrm{O} 0.03, \mathrm{KIO}_{3}, 0.001, \mathrm{KCr}\left(\mathrm{SO}_{4}\right)_{2}$ $12 \mathrm{H}_{2} \mathrm{O} 0.55$

The diet composition and nutrient content of the experimental diets is given in Table 1 .

\section{Experimental procedure}

Feeding management. After a 7-day preliminary period, a 7-day metabolism trial was conducted where daily feed intake and excreta were measured. During the preliminary period, the animals were fed ad libitum with commercial feed for rats (MF Shimizu Experimental Materials Co.; 0.05 ppm Se detected as a contaminant). Fresh water (distilled) was made available at all times. Body weight (BW) was determined before and after the metabolism trial. Feed intake and water consumption were checked at 10 a.m. every day during the trial. The animals were cared for throughout the experimental period according to the Guide for the Care and Use of Laboratory Animals (Kyoto University Animal Care Committee).

Sample collection. Total faecal and urinary excretions were collected. Faecal samples were oven-dried at $60^{\circ} \mathrm{C}$ for $48 \mathrm{~h}$, ground and stored prior to analysis. Similarly, urine was collected using filter papers that were placed under the cages. Absorbed urine was dried and stored prior to analysis.
On the final day of the trial, all rats were anaesthetized using diethyl ether (Wako Pure-Chemical Industrial Co.) and blood samples were collected through the ventral aorta using a heparinized syringe. One millilitre of whole blood was taken from the syringe and stored at $-20^{\circ} \mathrm{C}$ prior to Se analysis, while the remaining portion was centrifuged at $1600 \mathrm{~g}$ for $20 \mathrm{~min}$ to separate plasma from blood corpuscles. Vital organs such as the brain, lung, heart, liver, spleen, kidney and the thigh muscles were removed, washed with Ringer's solution with vitamin B1 (Mitaka Pharmaceutical Co.) and stored at $-20^{\circ} \mathrm{C}$.

\section{Analytical methods}

Dry matter $(\mathrm{DM})$, organic matter $(\mathrm{OM})$, crude protein $(\mathrm{CP})$ and ether extract (EE) contents of the diets and faeces were measured according to the AOAC procedure (1960).

After wet digestion with nitric and perchloric acids $(3: 1 \mathrm{v} / \mathrm{v})$, the Se contents of the diets, faeces, urine, whole blood and vital organs were determined by the fluorometric method of Watkinson (1966). All of the data were subjected to ANOVA (Yoshida, 1975) using a commercially available computer programme (SAS, 1999).

\section{Results}

\section{Nutrient content of dietary treatments}

Table 1 presents the nutrient content of the experimental diets. Except for vitamin E, variations in the $\mathrm{OM}$ and $\mathrm{CP}$ contents of the experimental diets are quite low. This would indicate that the diets are iso-nitrogenous, negating the possible advantage of incorporating microbial matter in the Se-supplemented groups. Both bacteria and protozoa are rich sources of organic nutrients.

\section{Selenium concentration in rumen microbes}

The $0.4 \mathrm{mg} \mathrm{Se} \cdot \mathrm{kg}^{-1} \mathrm{DM}$ incorporated into the diet made up of timothy hay and concentrate fed to the host animal produced $0.42 \mathrm{mg}$ protozoal $\mathrm{Se} \cdot \mathrm{kg}^{-1} \mathrm{DM}$, while the harvested bacterial Se was only $0.26 \mathrm{mg} \cdot \mathrm{kg}^{-1} \mathrm{DM}$ (Table 2). With this concentration, the total volume of collected rumen fluid was $580 \mathrm{ml}$ for protozoa and $1630 \mathrm{ml}$ for bacteria to arrive at a similar concentration of $0.67 \mathrm{mg}$ $\mathrm{Se} \cdot \mathrm{kg}^{-1} \mathrm{DM}$. It is interesting to note that protozoa had a better ability to synthesize cellular Se than bacteria utilizing a similar rumen substrate. This result could be explained by the nature of protozoa to engulf bacteria in the rumen (Hungate, 1978). 
Table 2. Chemical composition of rumen microbes collected from sheep fed $0.4 \mathrm{mg}$ selenite per $\mathrm{kg}$ of dry matter

\begin{tabular}{lcc}
\hline Indices & Protozoal fraction & Bacterial fraction \\
\hline Dry matter, $\%$ & 93.6 & 84.3 \\
Crude protein, \% & 26.6 & 24.1 \\
Selenium $(\mathrm{Se}), \mathrm{mg} \cdot \mathrm{kg}^{-1 *}$ & 0.42 & 0.26 \\
\hline${ }^{*}$ dry matter basis & &
\end{tabular}

\section{Feed and water consumption, body weight}

Table 3 presents the average daily feed and water intake, and body weight of rats fed with different Se-sources. Feed intake did not vary significantly, but water consumption was found to be higher in the microbial Se-supplemented group. Animals fed BSe had the highest $(P<0.05)$ water intake, followed by those in the PSe, control and ISe groups.

Table 3. Feed and water intake of rats as influenced by different forms of Se supplements

\begin{tabular}{|c|c|c|c|}
\hline Control & ISe diet ${ }^{1}$ & PSe $\operatorname{diet}^{2}$ & BSe $\operatorname{diet}^{3}$ \\
\hline \multicolumn{4}{|l|}{ Feed, $\mathrm{g} \cdot$ day $^{-1}$} \\
\hline $13.91 \pm 0.32^{* a}$ & $14.80 \pm 0.18^{b}$ & $14.76 \pm 0.13^{b}$ & $14.46 \pm 0.76^{\mathrm{ab}}$ \\
\hline $\begin{array}{l}\text { later, } \mathrm{ml} \cdot \text { day }^{-1} \\
\qquad 180.94 \pm 10.71^{\mathrm{a}}\end{array}$ & 169.04 & & \\
\hline
\end{tabular}

${ }^{1}$ inorganic Se diet; ${ }^{2}$ protozoal Se diet; ${ }^{3}$ bacterial Se diet; ${ }^{*}$ mean \pm SE of 10-12 animals; ${ }^{a b}$ means with different superscipts within a row are significantly different at $P \leq 0.05$

Despite a similar initial BW, rats fed BSe had the lowest $(P<0.05)$ liveweight after 7 days of the balance trial (Table 4$)$. The $4 \mathrm{~g}$ gain in weight of animals in the BSe group is more than 3-fold lower than the $12.9 \mathrm{~g}$ total gain in weight in the ISe group. There were no significant differences in the liveweight among animals across the control, PSe and ISe groups.

\section{Apparent digestibility of nutrients}

Dry matter, OM and CP digestibility showed almost similar trends across treatments, with ISe having the highest numerical value, followed by the control, PSe and BSe groups (Table 4). The differences in $\mathrm{CP}$ and EE digestibility between ISe and

Table 4. Body weight changes and apparent digestibility of nutrients in rats fed diets with different forms of Se supplements

\begin{tabular}{|c|c|c|c|c|}
\hline Indices & Control & ISe diet ${ }^{1}$ & PSe diet ${ }^{2}$ & BSe $\operatorname{diet}^{3}$ \\
\hline \multicolumn{5}{|l|}{ g/head } \\
\hline initial & $179.4 \pm 2.5^{*}$ & $178.6 \pm 1.5$ & $181.0 \pm 2.5$ & $177.2 \pm 2.1$ \\
\hline final & $190.7 \pm 2.3^{a}$ & $191.5 \pm 1.4^{a}$ & $190.9 \pm 1.5^{a}$ & $181.2 \pm 2.6^{b}$ \\
\hline gain & $11.3 \pm 1.6^{a}$ & $12.9 \pm 0.9^{a}$ & $10.0 \pm 1.8^{\mathrm{a}}$ & $4.0 \pm 1.8^{b}$ \\
\hline Dry matter, \% & $73.6 \pm 2.5^{\mathrm{a} a \mathrm{~b}}$ & ab $76.1 \pm 2.3^{a}$ & $71.3 \pm 2.8^{\mathrm{ab}}$ & b $66.6 \pm 2.7^{b}$ \\
\hline $\begin{array}{l}\text { Organic } \\
\text { matter, \% }\end{array}$ & $76.2 \pm 2.3^{a}$ & a $78.0 \pm 2,1^{a}$ & $73.1 \pm 2.6^{\mathrm{ab}}$ & $67.8 \pm 2.8^{b}$ \\
\hline $\begin{array}{l}\text { Crude } \\
\quad \text { protein, } \%\end{array}$ & $74.3 \pm 2.1^{\mathrm{a}}$ & $77.4 \pm 2.4^{a}$ & $70.6 \pm 2.9^{a}$ & $58.6 \pm 3.0^{b}$ \\
\hline Crude fat, \% & $74.7 \pm 4.0^{\mathrm{a}}$ & $82.6 \pm 1.7^{b}$ & $81.5 \pm 1.3^{\mathrm{ab}}$ & $68.3 \pm 2.2^{c}$ \\
\hline
\end{tabular}

PSe were not significant $(P>0.05)$, however. Dry matter and OM digestibility of microbial tissuesupplemented diets were the same, but protozoa provided more digestible nutrients that resulted in higher $(P<0.05) \mathrm{CP}$ and $\mathrm{CF}$ digestibility in group PSe compared with BSe. Although rumen microbes are a rich source of tissue protein, only $58.6 \%$ of the diet containing bacterial protein was digested, while the diet with protozoal protein had a digestibility of $70.6 \%$.

\section{Selenium balance}

As shown in Table 5, Se intake was about 3 times higher $(P<0.05)$ in Se-supplemented diets than in the control (Table 1). The consumed Se in the control was contributed by the various feed ingredients that composed the diet. Although total feed consumption varied significantly $(P<0.05)$ among the Se-supplemented diets, Se intake was not affected.

Table 5. Selenium balance in rats as influenced by different forms of Se supplements

\begin{tabular}{lllll}
\hline Indices & Control & ISe diet $^{1}$ & PSe diet $^{2}$ & BSe diet $^{3}$ \\
\hline ng $\cdot \mathrm{kg}^{-1} \mathrm{BW}^{0.75} \cdot$ day $^{-1}$ & & & \\
intake & $2523 \pm 188^{\star a}$ & $7938 \pm 563^{\mathrm{b}}$ & $7229 \pm 222^{\mathrm{b}}$ & $7049 \pm 1130^{\mathrm{b}}$ \\
feacal excretion & $1393 \pm 186^{\mathrm{a}}$ & $3513 \pm 826^{\mathrm{b}}$ & $3117 \pm 1503^{\mathrm{a}}$ & $2513 \pm 1631^{\mathrm{a}}$ \\
urinary excretion & $34.7 \pm 5.9$ & $134.9 \pm 63.7$ & $61.8 \pm 36.1$ & $78.3 \pm 40.5$ \\
absorbed Se & $1129 \pm 240^{\mathrm{a}}$ & $4424 \pm 945^{\mathrm{b}}$ & $4112 \pm 1435^{\mathrm{b}}$ & $4535 \pm 2418^{\mathrm{ab}}$ \\
retained Se $^{5}$ & $1094 \pm 237^{\mathrm{a}}$ & $4289 \pm 931^{\mathrm{b}}$ & $4050 \pm 1583^{\mathrm{b}}$ & $4457 \pm 2448^{\mathrm{b}}$ \\
Se utilization $^{7} \%$ & $96.2 \pm 1.4$ & $98.3 \pm 1.9$ & $99.0 \pm 1.0$ & $98.6 \pm 1.9$ \\
\hline
\end{tabular}

$1,2,3,4$ see Table 3; ab means with different superscipts within a row are significantly different at $P \leq 0.05 ;{ }^{5}$ Se consumption minus faecal Se; ${ }^{6}$ Se consumption minus (faecal Se plus urinary Se); ${ }^{7}$ retained Se/absorbed Se x 100

Absorbed and retained Se was significantly higher $(P<0.05)$ in Se-supplemented groups than in the control. On the other hand, faecal Se excretion was high in ISe, and urinary Se excretion tended to be high in Se-supplemented groups as compared with the control. The high retention of absorbed Se in PSe and BSe, which reached 98.6\% and 99.0\%, respectively, was due to the small amount of Se excreted through the urine.

\section{Se content of blood, muscle and organs}

The Se concentrations in whole blood, muscles and vital organs are shown in Table 6. Except for BSe, the positive effect of Se supplementation was very evident as blood Se concentrations of rats fed ISe and PSe were higher $(P<0.05)$ than those in controls. No significant effect on blood Se concentration was observed between the two microbial Se sources, thus both PSe and BSe were similar in terms of absorption and incorporation into erythrocytes. Except for the liver and kidney $(P<0.05)$, other organs showed similar Se concentrations across treatments. 
Table 6. Se concentration in whole blood, muscle and other organs of rats as influenced by different forms of Se supplements

\begin{tabular}{|c|c|c|c|c|}
\hline Items & Control & ISe diet ${ }^{1}$ & PSe $\operatorname{diet}^{2}$ & BSe $\operatorname{diet}^{3}$ \\
\hline \multicolumn{5}{|c|}{ Haematocrit, \% } \\
\hline & $41.5 \pm 0.8^{*}$ & $42.3 \pm 0.5$ & $42.5 \pm 0.8$ & $41.5 \pm 0.8$ \\
\hline \multicolumn{4}{|c|}{ Whole blood, } & $208.9 \pm 10.1^{a c}$ \\
\hline \multicolumn{5}{|c|}{$\mathrm{ng} \mathrm{Se} \cdot \mathrm{g}^{-1}$ wet tissues } \\
\hline liver & $392.6 \pm 55.6^{\mathrm{ab}}$ & $533.8 \pm 54.4^{a}$ & $209.8 \pm 43.6^{b}$ & $367.7 \pm 71.4^{\mathrm{ab}}$ \\
\hline kidney & $824.5 \pm 26.8^{\mathrm{ab}}$ & $908.2 \pm 70.0^{a}$ & $865.2 \pm 14.5^{\mathrm{a}}$ & $690.9 \pm 42.0^{b}$ \\
\hline spleen & $234.8 \pm 11.8$ & $227.1 \pm 26.1$ & $247.7 \pm 14.5$ & $245.3 \pm 19.9$ \\
\hline brain & $111.6 \pm 6.9$ & $120.8 \pm 6.0$ & $93.3 \pm 18.7$ & $95.5 \pm 13.0$ \\
\hline heart & $222.2 \pm 9.5$ & $204.7 \pm 9.2$ & $219.8 \pm 17.0$ & $227.6 \pm 6.4$ \\
\hline lung & $189.2 \pm 11.4$ & $203.1 \pm 10.4$ & $228.0 \pm 18.6$ & $209.5 \pm 17.8$ \\
\hline muscle $^{4}$ & $119.5 \pm 7.4$ & $126.4 \pm 3.9$ & $126.0 \pm 4.4$ & $123.6 \pm 5.5$ \\
\hline
\end{tabular}

$1,2,3,4$ see Table $3 ;{ }^{5}$ a muscle of the thigh; ${ }^{a, b}$ means with different superscipts within a row are significantly different at $P \leq 0.05$

A different trend was observed in the effect of Se supplementation on the total amount of $\mathrm{Se}$ stored in the thigh muscle and different vital organs (Table 6). Selenite and BSe supplementation resulted in more retained Se in the liver, kidney, brain and spleen of rats than those fed PSe. No significant differences were noted in the total Se content of the heart and lung as influenced by Se supplementation.

\section{Discussion}

Diets, feed and water intake, and nutrient digestibility. The addition of selenite to the diet of sheep produced $0.40 \mathrm{~g}$ microbial matter $\mathrm{Se}$ per $\mathrm{kg}$ rumen matter, which is comparable to the $0.45 \mathrm{mg}$ microbial $\mathrm{Se} \cdot \mathrm{kg}^{-1} \mathrm{DM}$ from our previous study (Fujihara and Ichinohe, 2012). This value is twice the $0.2 \mathrm{mg} \mathrm{Se} \cdot \mathrm{kg}^{-1} \mathrm{DM}$ reported by Serra et al. (1997), despite the similar feeding rate of selenite to the host animal.

In addition to the elevated Se content in groups PSe and BSe, their vitamin E content was also higher than the control. This could be attributed mainly to the inclusion of rumen bacteria and protozoa influencing the influx of ingested vitamin $\mathrm{E}$ through rumen microbial activity (Chikunya et al., 2004). Likewise, the greater amount of bacterial matter in BSe resulted in a higher dietary vitamin $\mathrm{E}$ content than PSe. With a lower Se concentration per unit of bacterial tissue, its inclusion rate was adjusted to maintain an iso-Se level among the Se-supplemented diets. Therefore, protozoa could provide a greater amount of Se than bacteria per unit of microbial matter.As shown in Table 3, water consumption of rats fed diets with rumen microbial Se tended to be higher than those fed other diets. Some microbial matter in PSe and BSe, could have stimulated thirst, although the substances that triggered higher water intake in the present experiment have not been identified yet.

The low consumption in the BSe group could be attributed to the low digestibility of its nutrient contents. With similar ingredients used in formulating the various experimental diets, the $32 \%$ inclusion rate of bacterial matter greatly influenced nutrient digestibility in the BSe group. One of the known factors that tend to adversely affect digestibility of bacterial matter is its high content of cell wall constituents, which are mostly indigestible substances.

Se balance and utilization. Selenium in the body is eliminated via three routes, namely, urinary excretion through the kidney, faecal output through the lower digestive tract, and respiratory excretion through the mouth. The amount and ratio of Se excretion through these routes are influenced mainly by the form and amount of dietary Se (Reilly, 1992). Selenium is absorbed mainly through the jejunum and caecum. Likewise, the rate of Se utilization depends largely on whether it is from organic or inorganic sources. In the lower gut, selenomethionine is absorbed up to $90 \%$ compared with only $60 \%$ for selenate when used as supplemental Se (Reilly, 1992). Selenium utilization can be measured as the difference between intake and output, with faecal Se appearing as insoluble inorganic Se or proteinbinding Se in almost similar proportions (Butler and Peterson, 1961). Despite similar Se consumption in the supplemented diets, Se excretion was highest in rats fed ISe. With similar Se output in PSe and BSe, these results indicate that rumen protozoa and bacteria are more available due to their higher digestibility and utilization. On the other hand, inorganic Se was poorly digested. Faecal Se even exceeded Se intake, indicating that selenite was unavailable.

The higher amount of Se in the liver, kidney and muscle of rats fed PSe and BSe further proved that microbial Se is more bioavailable than selenite. This result is similar to the findings of Serra et al. (1997), who reported higher Se concentrations in some vital organs of rats fed bacterial Se than in those supplemented with selenite or selenate. Likewise, Ortman and Pehrson (1999) observed the same positive effects of bacterial-Se supplementation in elevating the blood Se concentration of cattle, but not with selenate or selenite. The mechanism by which microbial Se is more available at the tissue level than inorganic Se sources was explained by Hudman and Glenn (1984). They concluded that microorganisms under the highly ionized rumen environment transform ${ }^{75} \mathrm{Se}$-selenite to a sulphur-amino acidselenium complex that is rendered unavailable to the host animal because of its strong ligand. Furthermore, 
rumen microbes have the capacity to reduce selenite, making it unavailable to ruminants (Hudman and Glenn, 1984). Selenium is incorporated in the blood stream upon absorption through the small intestine, and distributed into the various organs of the body, primarily the liver and kidney using $\alpha$-globulin as a carrier. Therefore, Se accumulation is highest in the liver and kidney, followed by other organs such as the spleen, pancreas and lung where Se retention is quite high. Conversely, the nerve cells and brain are not known to accumulate and retain significant amounts of Se (McDowell, 1985; Serra et al., 1997). Table 6 shows the significantly higher Se concentration in the kidney of rats in the Se-supplemented groups, which tends to support the previous observation of Serra et al. (1997). The loss of Se through the urine is highest in rats fed ISe. This might be attributed to the relatively high turnover rate of $\mathrm{Se}$ in the body because the Se level in the kidney and liver are highest in ISe. These results suggests that utilization of microbial Se is better than of inorganic Se (selenite). Both PSe and BSe were absorbed and retained in greater proportions than selenite in the body of rats, indicating higher bioavailability.

The liver and kidney are known to be the most sensible and acceptable index organs to evaluate Se status of an animal. Likewise, blood Se or glutathione peroxidase levels are important indicators in the clinical diagnosis of deficiency, excess, or toxicity syndrome. Selenium is readily incorporated in the erythrocytes, thus reflecting the availability of dietary Se (McDowell, 1985). Utilization of absorbed Se depends on the capacity of various organs to store and retain Se. The liver and muscles had the greatest proportion relative to total body mass, and their ability to store Se was highest compared with other tissues or organs of the body. Interestingly, these organs with the greatest Se concentration are the most vulnerable to manifesting clinical and subclinical deficiency symptoms. Muscular dystrophy or degeneration (calcification) of muscle tissues and liver necrosis in rats are known deficiency symptoms associated with a low dietary Se content (JSV, 1989; Lamand, 1989). Bouwstra et al. (2010) and Weiss (2012) showed that the effect of higher levels of dietary vitamin $\mathrm{E}$ or Se supplementation is their higher titre in dairy cows resulting in enhanced chemostatic and random migration of neutrophils and increased production of superoxides that reduce the incidence of mastitis. It is, therefore, important to provide diets with adequate amounts of Se to ensure normal physiological functions of these vital organs.

\section{Conclusions}

Rumen microbes can synthesize Se compounds in their cells that resemble selenite in terms of digestibility and bioavailability. Protozoa had a greater ability than bacteria to incorporate $\mathrm{Se}$, as indicated by the variation in microbial Se concentration collected from host animals (sheep) receiving a higher level of Se supplementation. Nonetheless, the supplementation of Se from microbial matter increased the concentration of plasma $\mathrm{Se}$ and retention in the muscles and some vital organs, like the liver and kidneys, with a similar efficiency as inorganic Se sources. Higher accumulation of Se in the liver and muscles provides better protection from the degenerating effects of peroxides that could result in Se deficiency symptoms such as liver necrosis and white muscle disease.

\section{Acknowledgements}

The authors are very grateful to the late Ms. Takako Awano for her valuable contributions in the conduct of the experiment.

\section{References}

AOAC, 1960. Association of Official Analytical Chemists, Official Methods of Analysis. $9^{\text {th }}$ Edition. Washington, DC

Butler G.W., Peterson P.J., 1961. Aspects of the fecal excretion of selenium by sheep. NZ J. Agr. Res. 4, 484-491

Bouwstra R.J., Nielen M., Stegeman J.A., Dobbelaar P., Newbold J.R., Jansen E.H.J.M., van Werven T., 2010. Vitamin E supplementation during the dry period in dairy cattle. Part I: Adverse effect on incidence of mastitis postpartum in a double-blind randomized field trial. J. Dairy Sci. 93, 5684-5695

Chikunya S., Demirel G., Enser M., Wood J.D., Wilkinson R.G., Sinclair L.A., 2004. Biohydrogenation of dietary n-3 PUFA and stability of ingested vitamin $\mathrm{E}$ in the rumen, and their effectson microbial activity in sheep. Brit. J. Nutr. 91, 539-550

Cousins F.B., Cairney I.M., 1961. Some aspects of selenium metabolism in sheep. Aust. J. Agr. Res. 12, 927-943

Czauderna M., Kowalczyk J., Krajewska K.A., 2004. Conjugated linoleic acid (CLA) content and fatty acids composition of muscles in rats fed isomers of CLA and selenium. J. Anim. Feed Sci. 13, 181-196

Czauderna M., Kowalczyk J., Krajewska K.A., 2011. Influence of dietary selenium level on the concentration of conjugated linoleic acid isomers, other fatty acids and amino acids in the liver and femoral muscles of rats. Czech J. Anim. Sci. 56, 81-94

Durand M., Kawashima R., 1980. Influence of minerals in rumen microbial digestion. In: Y. Ruckebush, P. Thivend (Editors).Digestive Physiology and Metabolism in Ruminants. MTP Press Ltd. Lancaster, pp. 375-408

Fujihara T., Ichinohe T., 2012. Bioavailability of rumen protozoan selenium fed to mice using tissue uptake technique. Bull. Fac. Life Environ. Sci. Shimane University 17, 3-7 
Fujihara T., Imamura T., Awano T., 2004. Basic study on Selenium nutrition in ruminants. Utilizability of microbial selenium (in Japanese). Proceeding of $103^{\text {rd }}$ Conference in Japanese Society of Animal Science, p. 66

Fujihara T., Matsui T., Hayashi S., Robles A.Y., Serra A.B., Cruz L.C., Shimizu H., 1992. Mineral status of grazing Philippine goats. II. The nutrition of selenium, copper and zinc of goats in Luzon Island. Asian-Austr. J. Anim. Sci. 5, 389-395

Grosicki A., Kowalski B., 2002. Lead, cadmium and mercury influence on selenium fate in rats. Bull. Vet. Inst. Pulawy 46, 337-343

Harrison J.H., Conrad H.R., 1984. Effect of selenium intake on selenium utilization by the nonlactating dairy cow. J. Dairy Sci. $67,219-223$

Harrtey W.J., 1963. Selenium and ewe fertility, Proc. NZ Soc. Anim. Prod. 23, 20-27

Hidiroglou M., Heaney D. P., Jenkins K.J., 1968. Metabolism of inorganic selenium in rumen bacteria. Can. J. Physiol. Pharmacol. 44, 229-232

Hungate R.E., 1978. The rumen protozoa. In: J.P. Kreier (Editor). Parasitic Protozoa, Vol. 2. Academic Press. New York, pp. 655-695

Hudman J.F., Glenn A.R., 1984. Selenium uptake and incorporation by Selenomonas ruminantium. Arch. Microbiol. 140, 252-256

JSV (Japanese Society of Vitaminology), 1989. Vitamin Handbook, Shiyosei Vitamin (in Japanese). Tokyo-Kagaku-Dohjin, Tokyo, pp. 49-72

Lamand M., 1989. Selenium deficiency in animals. In: J. Neve, A. Favier (Editors). Selenium in Medicine and Biology. Walter de Gruyter. Paris, pp. 357-368

Lyons M.P., Papazyan T.T., Surai P.F., 2006. Selenium in food chain and animal nutrition: Lessons from nature - Review. AsianAustr. J. Anim. Sci. 20, 1135-1155

McDowell L.R., 1985. Nutrition of Grazing Ruminants in Warm Climates. Academic Press Inc. San Diego, pp. 275-286

NRC, 1978. Nutrient Requirements of Laboratory Animals. $3^{\text {rd }}$ Edition. National Academic Press. Washington, DC

NRC, 1983. Selenium in Nutrition - Revised Edition. National Academic Press. Washington, DC

NRC, 1985. Nutrient Requirements of Sheep. $6^{\text {th }}$ Edition. National Academic Press. Washington, DC

Nicholson J.W.G., MacQueen R.E., Bush R.S., 1991. Response of growing cattle to supplementation with organically bound or inorganic sources of selenium or yeast cultures. Can. J. Anim. Sci. $71,803-811$
Ortman K., Pehrson B., 1999. Effect of selenate as a feed supplement to dairy cows in comparison to selenite and selenium yeast. J. Anim. Sci. 77, 3365-3370

Paulson G.D., Baumann C.A., Pope A.L., 1968. Metabolism of 75Seselenite, 75 Se-selenate, 75 selenomethionin and $35 \mathrm{~S}$-sulfate by rumen microorganisms in vitro. J. Anim. Sci. 27, 497-504

Peterson P.J., Spedding D.J., 1963. The excretion by sheep of 75 Selenium incorporated into red clover (Trifolium pretense L.) - the chemical nature of the excreted selenium and its uptake by three plants species. NZ J. Agr. Res. 6, 13-23

Reilly C., 1992. Selenium in Food and Health. Blackie Academic \& Professional. London, pp. 33-49

Saruwatari K., Ikeda N., 1993. Kagaku-shojiten (in Japanese). Kagaku-shojiten, Sanseidoh Co. Tokyo, pp. 215

SAS, 1999. User' Guides. StatView. Version 5. Statistical Analysis System Institute Inc. Cary, NC

Schomburg L., Schweizer U., Köhrle J., 2004. Selenium and selenoproteins in mammals: extraordinary, essential, enigmatic. Cell. Mol. Life Sci. 61, 1988-1995

Serra A.B., Nakamura K., Matsui T., Harumoto T., Fujihara T., 1994. Inorganic selenium for sheep. I. Selenium balance and selenium levels in the different fluid fractions. Asian-Austr. J. Anim. Sci. 7, 83-89

Serra A.B., Serra S.D., Fujihara T., 1996. Influence of dietary protein on the apparent absorption and retention of selenium in sheep. Asian-Austr. J. Anim. Sci. 9, 551-556

Serra A.B., Serra S.D., Shinchi K., Fujihara T., 1997. Bioavailability of rumen bacterial selenium in mice using tissue. Biol. Trace Elem. Res. 58, 255-261

Trinder N., Woodhouse C.D., Renton C.P., 1969. Effect of vitamin E and selenium on the incidence of retained placenta in dairy cows. Vet. Res. $85,550-553$

Watkinson J.H., 1966. Fluorometric determination of selenium in biological material with 2,3-diaminonaphtalene. Anal. Chem. 38, 92-97

Whanger P.D., Weswig P.H., Oldfield J.E., 1978. Selenium, sulfur and nitrogen levels in ovine rumen microorganisms. J. Anim. Sci. 46, 515-519

Weiss W.P., 2012. Minerals and vitamins for dairy cows. In: Proceedings of Herd Health and Nutrition Conference. Syracuse, NY and West Lebanon, NH, pp. 27-36

Yoshida, M., 1975. Design of Experiments for Animal Husbandry (in Japanese). Yokendo, Tokyo 